\title{
WHY DO MUZAKI PAY ZAKAT THROUGH INSTITUTIONS? THE THEORY OF PLANNED BEHAVIOUR APPLICATION
}

\author{
Muhammad Akbar Fadzkurrahman Annahl ${ }^{1}$, Ali Chamani Al Anshory ${ }^{2}$ and \\ Mahdiah Aulia ${ }^{3}$ \\ ${ }^{1}$ Universitas Gadjah Mada, Indonesia, akbarfadzkurrahman@mail.ugm.ac.id \\ ${ }^{2}$ Pusat Kajian Strategis BAZNAS, Indonesia, ali.chamani@puskasbaznas.com \\ ${ }^{3}$ International Islamic University of Malaysia, Malaysia, mahdiah.aulia@gmail.com
}

\begin{abstract}
This research investigates the factors that influence the intention of paying zakat maal through zakat institutions. By paying zakat in such a way, muzaki can support zakat institutions in eradicating poverty through a broader and deeper distribution of zakat funds. However, the realisation of zakat collection remains low compared to its potential, which means that the number of muzaki who pay zakat through institutions also remains limited. The research applied the extended theory of planned behavior (TPB) framework with knowledge, trust, and perceived ease of use as additional variables to address the issue in question. Subsequently, an online questionnaire was conducted using the purposive sampling method, which generated 383 respondents. The primary data were examined using the PLS-SEM method. Based on the results, all the proposed hypotheses were accepted. Considering that paying zakat via institutions provides a better way to assist rightful recipients, various suggestions are made to zakat managers, policymakers, and muzaki. The research highlights a new perspective by examining the intention of paying zakat maal through institutions with the additional variables of knowledge, trust, and perceived ease of use.
\end{abstract}

Keywords: Knowledge, Theory of planned behavior, Trust, Zakat institutions.

JEL classification: A00; A10; A11; Z12.

Article history:

Received : October 15, 2020

Revised : January 16, 2021

Accepted : February 8, 2021

Available online : March 31, 2021

https://doi.org/ 10.21098/jimf.v7i0.1313 


\section{INTRODUCTION}

\subsection{Background}

Zakat is one of the pillars of Islam, reflecting the concern of Islamic teaching for social justice. From an economic perspective, Wahab and Rahman (2011) state that zakat can positively contribute to aggregate consumption, savings and investment, the aggregate supply of labour and capital, poverty alleviation, and economic growth. Beik and Arsyianti (2016), using the CIBEST model, show that the distribution of zakat through zakat institutions could increase the welfare index by $96.8 \%$, while at the same time reducing the poverty indexes. Such impactful distribution is due to the ability of zakat institution programmes to assist the mustahik in obtaining sustainable income. Therefore, this implies the advantage of zakat funds being professionally managed.

Even though Indonesia, as the country with the largest Muslim population, is recognised as the most generous nation worldwide (Charities Aid Foundation, 2018), its zakat collection remains far from its potential. According to the latest statistical data of Indonesia Zakat Outlook (BAZNAS, 2019), total zakat collection in 2018 was IDR8 trillion, which is only 3.5\% of the total potential of IDR233.8 trillion. For this potential to be fully realised, broader and deeper assistance of funds can be received by the mustahik. Therefore, when muzaki (zakat payer) pay zakat through institutions, the potential can be optimised for positive impacts.

As shown in Table 1, the economic growth of the ASEAN-5 countries is expected to fall drastically by the IMF (2020), Asian Development Bank (2020), and World Bank (2020). Significantly for Indonesia, the IMF (2020) also forecast that the unemployment rate would increase by $7.5 \%$ in 2020. Indonesia's economic growth was also projected to fall in 2020 to $0.5 \%$, before recovering in 2021 (IMF, 2020). This economic condition would reduce the number of muzaki, while continuously creating new mustahik (zakat recipient) in the country.

Table 1.

ASEAN-5 Expected Economic Growth (in Percentages)

\begin{tabular}{lcccccc}
\hline \multirow{2}{*}{ Country } & \multirow{2}{*}{$\mathbf{2 0 1 9}$} & \multicolumn{3}{c}{ Prediction for 2020 } & \multicolumn{2}{c}{ Prediction for 2021 } \\
\cline { 3 - 7 } & & IMF & ADB & WB Baseline & IMF & ADB \\
\hline Indonesia & 5.0 & 0.5 & 2.5 & 2.1 & 8.2 & 5.0 \\
Malaysia & 4.3 & -1.7 & 0.5 & -0.1 & 9.0 & 5.5 \\
Thailand & 2.4 & -6.7 & -4.8 & -3.0 & 7.6 & 2.5 \\
Philippines & 5.9 & 0.6 & 2.0 & 3.0 & 7.6 & 6.5 \\
Vietnam & 7.0 & 2.7 & 4.8 & 4.9 & 7.0 & 6.8 \\
\hline
\end{tabular}

Sources: IMF (2020), Asian Development Bank (2020), and World Bank (2020).

Based on this situation, the issue of zakat collection has become an essential topic when discussing any increase in the role of zakat institutions. Several kinds of research have highlighted institutional issues, such as the lack of accountability (Firmansyah \& Devi, 2017) and the lack of synergies or partnerships between zakat institutions (Huda, 2014). These factors relate to how the muzaki trust the institutions' donation funds. Furthermore, Yusuf and Derus (2013) argue that at least three factors contribute to the low level of zakat realisation: the concentration 
on zakat fitr; the lack of accurate information on the concept of zakat on various zakatable goods; and the failure of zakat institutions. These factors indicate that broadened discussion may include zakat maal (zakat on wealth) and muzakis' knowledge about zakat. Another consideration is the application of technology, which can ease the payment of zakat. If there exists the possibility of online payment with less effort involved, muzaki will feel more at ease fulfilling their obligations (Jamaludin, Wahab \& Hamed, 2017). Therefore, this research discusses several potential variables that might affect the intention of muzaki to pay zakat through institutions.

An intriguing perspective from which to study this intention is through behavioural research. By recognising the muzakis' response, zakat institutions can manage a supportive relationship with them and other stakeholders (Kasri, 2013). Exploration of donors' or muzakis' intention or behaviour is an emerging field of study. One of the well-known frameworks for analysing intention or behaviour is the theory of planned behavior (TPB). TPB was developed by Ajzen (1991) and provides a conceptual framework for predicting and understanding certain behaviours in specific contexts. It can examine detailed ways of improving intentions in its development (Ajzen, 2011). By applying the framework, this research can provide perspectives to either zakat institutions or muzaki to raise the collection of zakat funds with the final aim of assisting needy people. Various studies of charities or religious institutions using TPB have been conducted in Australia (Knowles, Hyde \& White, 2012; Smith \& McSweeney, 2007); Canada (Mittelman \& Rojas-Méndez, 2018); Nigeria (Farouk, Md Idris \& Saad, 2018); Malaysia (Kashif, Sarifuddin \& Hassan, 2015); and Indonesia (Kasri \& Ramli, 2019; Widiyanto, Zaenudin, Santoso \& Sumiati, 2019). Therefore, this research applied behaviour-related research by optimising the TPB framework to complement the efforts in solving zakat collection issues in Indonesia.

The distinction of the research lies in two main aspects. First, by analysing the factors that influence the preferences of muzaki in paying zakat, the study recommends at least two main issues for zakat institutions to raise their level of collection, such as gaining trust from society and increasing people's knowledge. Second, an extended TPB with the addition of perceived ease of use, trust, and knowledge is expected to provide more comprehensive dimensions that influence the intention of muzaki to allocate their zakat funds to zakat institutions.

\subsection{Objective}

The objective of the research is to empirically investigate the variables influencing intentions and attitudes with regard to paying zakat through zakat institutions among muzaki in Indonesia. A theoretical framework was developed based on TPB, which examines the influence of attitude, subjective norms, and perceived behavioural control on the intention to pay zakat through institutions. Furthermore, the theory is extended by including the variables of perceived ease of use, knowledge, and trust. Based on the objective and the background, the research questions developed are:

1. How do the attitude, subjective norms, perceived behavioural control, and perceived ease of use variables influence the intention to pay zakat through institutions? 
2. What is the relationship between the knowledge and trust variables and attitude?

The structure of the study is as follows. The first section describes the research background and objectives, while the second reviews the literature related to the theory of planned behavior. This section discusses how zakat is regulated, and refers to previous studies on TPB and zakat. The third section describes the research method and develops the hypotheses. The fourth section explains the findings and analysis, while the fifth provides the research conclusions and implications.

\section{LITERATURE REVIEW}

\subsection{Background Theory}

The situation of zakat payment in Indonesia can be illustrated from a regulatory perspective. Beik (2015) characterised four zakat regulation typologies, as deliberated by zakat law and its system. As shown in Table 2, these include a comprehensive model (Type 1), a partial model (Type 2), a secular model (Type 3), and an impossible model (Type 4). The comprehensive model (Type 1) includes the Zakat Act, and the system mandates zakat payment. This is the ideal model, and the system was also implemented in the prophet (PBUH) era, when society took responsibility to pay zakat. In the partial model (Type 2), zakat is not regulated as an obligation, although the Zakat Act is present. Beik (2015) explains that the existence of the Zakat Act only covers the management aspect of zakat. However, in the secular model (Type III), there is no state involvement in zakat management, so collection and distribution are solely based on people's willingness to manage zakat. Finally, the impossible model (Type IV) refers to the impossible situation of making zakat mandatory, but without regulation.

Table 2.

Typology of Zakat Regulation

\begin{tabular}{lcc}
\hline & Obligatory Zakat System & Voluntary Zakat System \\
\hline \multirow{2}{*}{ Regulation } & Type I: & Type II: \\
& Comprehensive Model & Partial Model \\
\hline \multirow{2}{*}{ No Regulation } & Type IV: & Type III: \\
& Impossible Model & Secular Model \\
\hline
\end{tabular}

Source: Beik (2015).

Based on the model, Indonesia applies the partial version (Type II), which means zakat is regulated, but payment is voluntary. Unfortunately, this voluntary system is the reason for the unrealised potential for zakat collection in the country; the prospective total of IDR217 trillion has not been achieved (Firdaus, Beik, Irawan \& Juanda, 2012). Even though zakat is mandatory for eligible Muslims, muzaki might not pay their share due to a lack of literacy or willingness. Moreover, muzaki have the option not to channel their zakat to zakat institutions, despite the advantages this provides in realising the aspiration of zakat.

There are several notable benefits of paying zakat through zakat institutions. First, zakat has been historically managed by an organised amil institution, which 
has collected and distributed zakat since the time of Prophet Muhammad (peace be upon him). Qardawi (2000) argues that having an institution or well-structured organisation to collect and distribute zakat has been necessary since the early zakat period. The organised and administered functions of institutions could enhance the impact of zakat as a socioeconomic justice instrument in Islam. Second, paying zakat through registered institutions brings more maslahah (benefits) to society. Notably, when muzaki distribute zakat directly to mustahik, it will only circulate to the muzaki's immediate circles, and hence the impact wil be minimal. On the contrary, zakat institutions have more capability to utilise the zakat funds to empower mustahik economically on a larger scale and with better strategy.

Furthermore, distribution by zakat institution entails two necessities: spiritual and material needs. These needs are measured using the CIBEST model developed by Beik and Pratama (2016). Several studies have discussed the distribution impact using the model. First, utilising the CIBEST model approach, Beik and Pratama (2016) found that the zakat fund programme under zakat institutions, namely Dompet Dhuafa, was able to reduce material, spiritual and absolute poverty by $49.6 \%, 1.6 \%$, and $12.3 \%$, respectively, while the welfare index increased by $63.7 \%$. Second, Beik and Arsyianti (2016), using the CIBEST model for the zakat program by BAZIS DKI Jakarta and Dompet Dhuafa, found that the welfare index increased by $96.8 \%$, while material, spiritual and absolute poverty were reduced by $30.15 \%$, $100 \%$, and $91.30 \%$ repectively. Therefore, these results imply the vital role zakat institutions play in positively impacting society.

Slowdowns in the economy have a substantial impact on the country's poverty rate. According to the SMERU Research Institute, the poverty rate would jump to above $11.4 \%$ if economic growth fell below 2.1\% (Suryahadi, Al Izzati \& Suryadarma, 2020). These numbers imply that there will be 5.9 million new poor people in addition to the 24.8 million already in Indonesia since September 2019. These effects need to be tackled, which can be assisted by zakat institutions' compliance with health protocols. Therefore, paying zakat through institutions has beneficial impacts. The zakat payment behaviour of muzaki needs to be examined to achieve a higher number of muzaki that pay zakat through institutions; one of the approaches to this is the application of TPB.

The theory was introduced by Ajzen (1991) and is an extension of the theory of reasoned action (TRA) that was previously formulated by Ajzen and Fishbein (1980). These theories propose that individuals will or will not perform an action based on their intention. Their belief about the behaviour in question can predict their intention. Notably, the behaviour is termed as 'planned' or 'reasoned' rather than unconscious or spontaneous (Ajzen, 2011). As shown in Figure 2, TPB posits three antecedents of behavioural intention: attitude, subjective norms, and perceived behaviour control. 


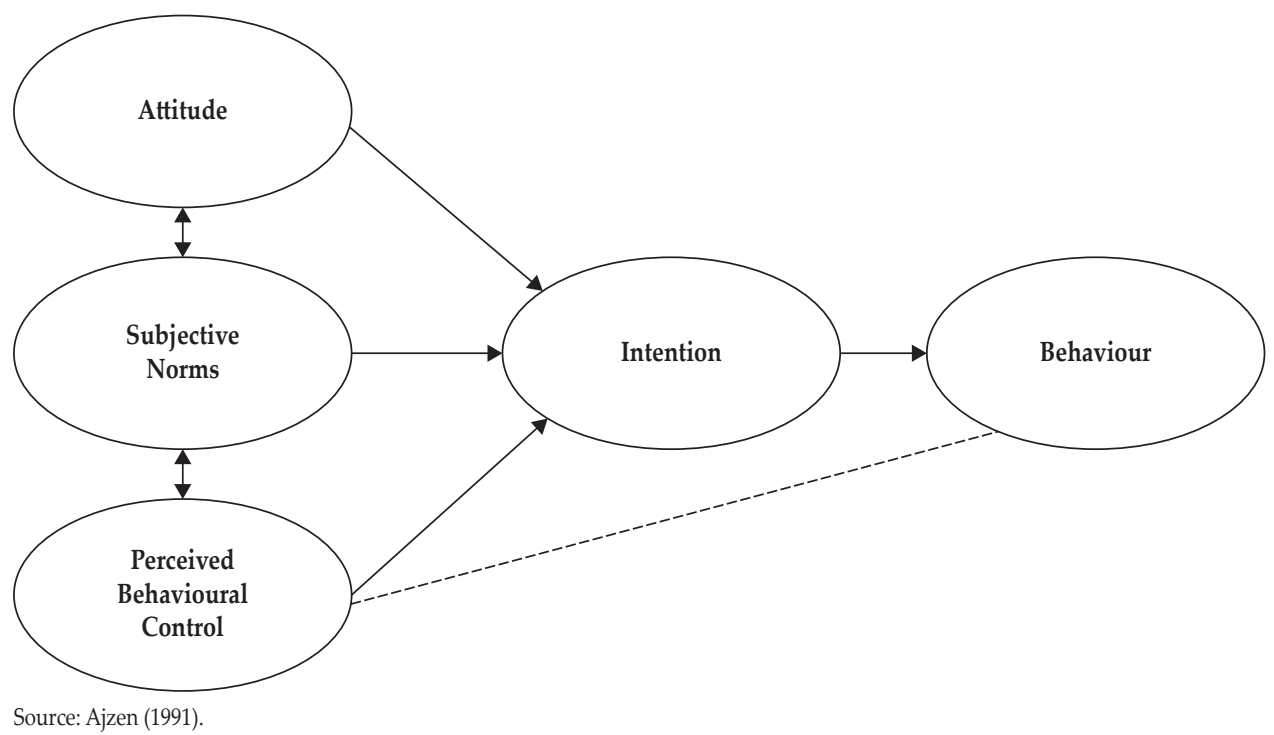

Figure 1.

Theory of Planned Behavior

The three components mentioned above create opportunities for an intention, which is assumed to be the behaviour's immediate antecedent. Various studies have used this framework in charity-related research. They have discussed young people's intention to donate to charities (Knowles, Hyde \& White, 2012); and donation behaviour to charitable organisations in Australia (Smith \& McSweeney, 2007) and Canada (Mittelman \& Rojas-Méndez, 2018). With more focus on the Islamic context, some studies have considered issues related to zakat or infaq. For example, they have examined the effect of religiosity on compliance with paying zakat on employment income (Farouk et al., 2018); and understanding the intention to pay infaq to Indonesian mosques (Kasri \& Ramli, 2019; Widiyanto et al., 2019). Therefore, by utilising TPB, it is expected that the research will examine the behaviour of muzaki in paying their zakat. It is hoped the research will fill the literature gap by providing novel observation of the motivation to pay zakat through institutions.

\subsection{Previous Studies}

Many studies have used TPB to investigate the relationships between attitude, subjective norms, perceived behavioural control, and intention in charities and religious organisations; zakat institutions can be categorised as both of these types of institution. Therefore, TPB can examine the influence of the intention to pay zakat through zakat institutions. Some researchers on the topic of zakat have also used the theory of reasoned action (TRA) to answer their research questions. TPB is an extension of TRA by adding perceived behavioural control as one of its main variables; therefore, this theory was applied in this study. 
Farouk et al. (2018) examined the moderating effect of religiosity on the relationship between attitude, subjective norms, and the intention to comply with zakat on employment income (ZEI) in Nigeria by applying TRA. They made 474 valid observations and analysed the data using partial least squares - structural equation modelling (PLS-SEM). Their study found that attitude and subjective norms had a significant relationship with the intention to pay ZIE. However, religiosity only had a moderating effect in the relationship between subjective norms and intention. Saad and Haniffa (2014) examined the factors influencing business zakat compliance behaviour in Malaysia also using TRA. They found that attitude and subjective norms positively and significantly affected zakat compliance behaviour through the mediation effect of the intention to behave. Furthermore, Bidin, Idris and Shamsudin (2009) found that subjective norms significantly influenced employment ZEI behaviour.

Another study by Jamaludin et al. (2017) investigated the relationship between perceived usefulness, perceived ease of use, security and privacy, and trust on online zakat usage. They found that trust, perceived ease of use, and perceived usefulness significantly influenced such usage. Therefore, zakat institutions should provide online systems that are reliable and user-friendly in order to increase the collection of zakat payment.

Saad, Farouk and Kadir (2020) used decomposed TPB to analyse the factors influencing the intention to comply with business zakat in the developing country of Nigeria. By analysing 524 responses with PLS-SEM, they found that attitudes toward zakat evasion, moral reasoning, peer influence, zakat knowledge, zakat distribution and perceived zakat board capital significantly influenced the intention to pay zakat among business people.

Studies on zakat have mostly discussed the factors that influence the compliance to pay it (Bidin et al., 2009; Farouk et al., 2018; Saad et al., 2020; Saad \& Haniffa, 2014). However, to date there has been little discussion about the factors that influence the decision to pay zakat through zakat institutions, rather than directly from muzaki to mustahik. It is essential to understand these factors so that zakat institutions can increase their collection levels. It has been explained above that paying zakat through zakat institutions has more advantages and benefits for society. Therefore, by using extended TPB with the additional variables of knowledge, trust and perceived ease of use, this paper aims to fill the knowledge gap by analysing the factors that influence the intention to pay zakat through institutions.

\subsection{Conceptual Framework}

Several studies on zakat have applied TRA, TPB, and decomposed TPB. This study uses extended TPB to explain muzaki's intentions to pay zakat through institutions. This approach can be used to investigate in more depth what variables affect intention, as discussed earlier. The conceptual framework shown in Figure 2 illustrates that the intention to pay zakat through zakat institutions is dependent on attitude, subjective norms, perceived behavioural control, and perceived ease of use. The perceived ease of use variable was added because of its potential in affecting the muzaki's intentions towards online zakat payment based 
on Jamaludin et al. (2017). Furthermore, in the subsequent studies conducted by Kasri and Ramli (2019) and Husin and Rahman (2016), the knowledge and trust variables influenced the attitude that determines intention.

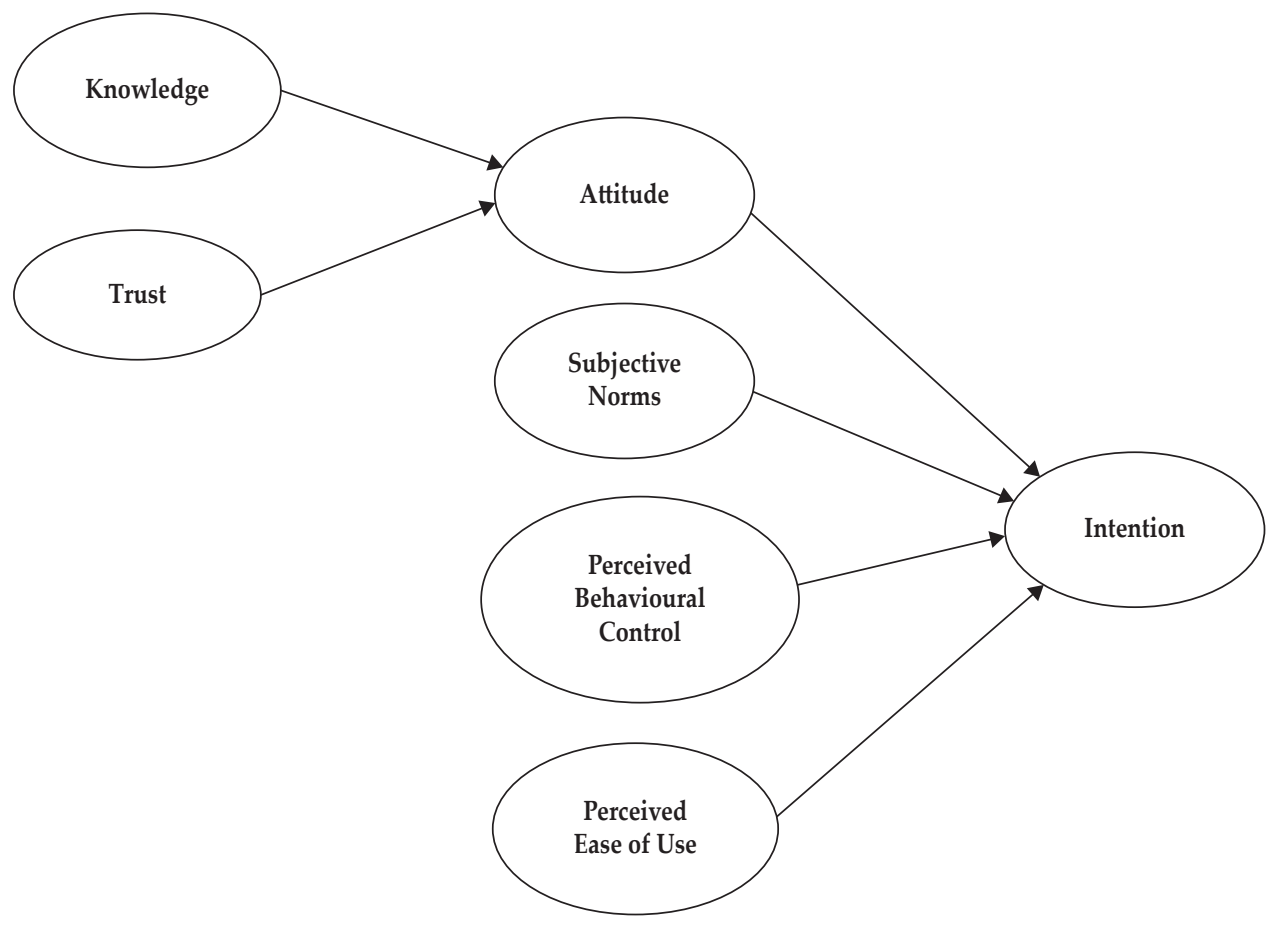

Source: Authors' Own.

Figure 2.

Conceptual Framework

\section{METHODOLOGY}

\subsection{Data}

An online questionnaire was employed to gather the data from Indonesia, mostly from Java and Sumatra islands. The use of an online questionnaire helped gather information from various persons through their responses to questions. At the same time, the data could be collected from a larger population, more quickly and at lower cost (Check \& Schutt, 2011). The questionnaire contained 31 TPB indicators (see Table 3), based on a six-item Likert scale, ranging from 1 (strongly disagree) to 6 (strongly agree) in order to achieve higher reliability and make respondents present their behaviour rather than giving neutral answers (Chomeya, 2010). The items were intended to measure the variables taken from previous studies and modified to fit the objectives of this research. The questionnaire was distributed via social media platforms to cover a larger population.

The sampling technique used was purposive sampling. The criteria for respondent selection were that they were muzaki and paid zakat maal. Muzaki is eligible to pay zakat based on nishab, which is the minimum amount of wealth that 
determines the "zakatibility" of a person, and the haul is the completion period of zakat assets. Notably, the haul for the zakat profession could be monthly, based on the income period. Therefore, some muzaki could pay their zakat 12 times a year.

Furthermore, by analysing both the muzaki of zakat and non-zakat institutions, a more comprehensive understanding of zakat payment preferences could be observed in order to create effective strategies and campaigns (Knowles et al., 2012). The initial data were gathered from 383 respondents, then filtered to 304 who met the research criteria. In line with Hair, Black, Babin \& Anderson (2010), the number of qualified samples was valid as the required sample was 5-10 times the number of indicators. Therefore, the sample would need to range between 155 and 310 respondents, which is higher than the largest number of structural paths directed to the latent constructs (Hair, Hult, Ringle \& Sarstedt, 2013).

\subsection{Model Development}

This research initially utilised Ajzen's (1991) theoretical framework including the three independent variables of attitude, subjective norms, and PBC. After investigating several previous studies, the independent variables of perceived ease of use, knowledge, and trust were added. These were hypothesised to relate with intention as the dependent variable. Intention was assumed to directly correlate with behaviour (Fishbein \& Ajzen, 2011), so it was not examined directly. Deductive reasoning was used, which means that the research started with the theoretical framework and used the data to confirm or reject ideas (Hussey \& Hussey, 1997). Therefore, the approach involved testing the theory underlying the phenomena being assessed, employing the extended theory of planned behavior.

\subsubsection{Intention}

Ajzen and Fishbein (1980) postulated that intention is the immediate predictor of behaviour and can indicate an individual's readiness to perform a given action. By using intention, the TPB that was developed by Ajzen (1991) is considered to be a proxy or intermediary and concludes that intention will directly shape human behaviour. Furthermore, Smith and McSweeney (2007) found that intention could predict behaviour, even though the variance was relatively small. For example, the intention to use BAZNAS for paying zakat should predict the behaviour of doing so. Therefore, without measuring behaviour directly, assessing intention could help predict it (Fishbein \& Ajzen, 2011).

\subsubsection{Attitude}

Ajzen (1991) argued that attitude means the information-processing approach developed from society's beliefs about certain behaviours. In other words, one's attitude towards behaviour can be defined as a person's positive or negative feeling as an evaluation effect about performing the practice targeted.

Furthermore, Pitchay, Thaker, Azhar, Mydin \& Thaker (2019) found that attitude significantly affected consumers' engagement in choosing Islamic banking, and hence it impacts intention when selecting an organisation. Therefore, 
the research mentioned above implies that attitude can influence preferences for different forms of institution.

Zakat-related research in Malaysia found that attitude was significantly related to individuals accomplishing zakat in the private and public sectors in Kuantan (Ali et al., 2017). Based on these studies, it is necessary to research the influence of attitude towards behaviour primarily related to paying zakat through zakat institutions. Therefore, the following hypothesis is proposed:

H1: Attitude has a positive impact on the intention to pay zakat through zakat institutions.

\subsubsection{Subjective Norms}

The more people perceive that others think that they should display certain behaviour, the greater their intention to do so. Sapingi, Ahmad, and Mohamad (2011) noted that subjective norms imply a personal act on participation in specific behaviour, strongly influenced by close people such as friends and family.

Some studies have found that subjective norms determined halal producers' antecedents in adopting Islamic banks (Jaffar \& Musa, 2016) and influenced people's selection of Islamic home financing in Malaysia (Taib, Ramayah \& Abdul Razak, 2008). In zakat research, Bidin et al. (2009) found that subjective norms significantly influenced ZEI compliance behaviour. It can be claimed that a person's interest to pay zakat through zakat institutions will be affected by subjective norms. Therefore, the associated hypothesis is:

H2: Subjective norms have a positive impact on the intention to pay zakat through zakat institutions.

\subsubsection{Perceived Behavioral Control (PBC)}

$\mathrm{PBC}$ means consideration of the control belief related to the factors that influence an individual's ability to perform the behaviour in question, together with the perceived power of the elements to facilitate or interfere with such behaviour (Ajzen, 2015).

In Malaysia, PBC is a determining predictor of the Islamic banks selected by consumers (Pitchay et al., 2019; Taib et al., 2008), and their preception of convincing Islamic home financing organisations (Alam, Janor, Zanariah, Wel \& Ahsan, 2012; Amin, 2008; Ibrahim, Fisol \& Haji-Othman, 2017). In charity-related research, Knowles et al. (2012) explored PBC as one of the significant and positive contributors that shows that young people's capacity in Australia to donate might affect their intention to do so. According to these studies, PBC as a predicting determinant of intention is expected to positively encourage people to pay zakat through zakat institutions. Therefore, $\mathrm{i}$ tis hypothesised that:

H3: PBC has a positive impact on the intention to pay zakat through zakat institutions.

\subsubsection{Perceived Ease of Use}

Davis (1989) defined perceived ease of use as the degree to which an individual believes that utilising a specific system will be free of effort. As mentioned earlier, 
the definition ranges from freedom to difficulty or great effort. Furthermore, this variable is related to zakat payment because one of the influencing factors for muzaki to do so is the ease of paying or access to zakat institutions (Mukhlis \& Beik, 2013).

Perceived ease of use is employed mainly in research that observes how technology can assist individuals' decision-making. In the zakat aspect, Jamaludin et al. (2017) also found that perceived ease of use was a significant factor that encouraged online zakat payment. Based on the literature, muzaki would prefer to pay zakat when the process is easy and user friendly. The higher the perceived ease of use among muzaki to pay zakat in zakat institutions, the greater their preference for this option. Therefore, it is proposed that:

H4: Perceived ease of use has a positive impact on the intention to pay zakat through zakat institutions.

\subsubsection{Knowledge}

Knowledge plays an essential role in muzaki's decision making. It is defined by Widiyanto et al. (2019) as a person's understanding of possibly bringing an action to do something. In the zakat payment context, when muzaki understand zakat knowledge, they tend to pay zakat using all the information they have obtained. Jamal, Yaccob, Bartikowski \& Slater (2019) argue that a high level of understanding of Islamic teachings and principles inspires Muslims to donate and give to charity. Husin and Rahman (2016) also found that knowledge had a significant effect on the attitude to participate in takaful products.

Sufficient zakat knowledge of the procedures of zakat institutions in collecting and distributing funds and of zakat regulation is vital for the awareness of society, and so is used to reflect knowledge variables in this research. It is expects that muzaki will pay zakat through institutions due to the organisational advantages and positive impacts that zakat institutions have. The following hypothesis was therefore developed:

H5: Knowledge has a positive relation to the attitude of paying zakat through zakat institutions.

\subsubsection{Trust}

Trust is an essential component in influencing muzaki's preference to pay zakat through institutions. In this research, trust represents the degree of zakat institutions' credibility and whether the community is assured by the institutions' actual ability related to zakat collection, management, and distribution (Widiyanto et al., 2019).

Several types of research have presented trust as an influencing variable. Kasri and Ramli (2019) indicated that it significantly impacts Indonesian Muslims' attitudes to donating money to mosques. Widiyanto et al. (2019) also highlighted that credibility and information from zakat institutions build the trust of muzaki. Based on these arguments, the degree of trust of muzaki in the institutions might affect such determination. Therefore, the proposed hypothesis is that: H6: Trust has a positive relation to the attitude of paying zakat through zakat institutions. 
The indicators for each variable were adopted from related previous works. The details are presented in Table 3.

Table 3.

\section{Latent Variable Indicators}

\begin{tabular}{lc}
\hline \multicolumn{1}{c}{ Indicator } & Adopted From \\
\hline Attitude & Alam et al., 2012 \\
$\begin{array}{l}\text { I prefer to pay zakat through institutions instead of a non-zakat } \\
\text { institution. }\end{array}$ & Ali and Hatta, 2014 \\
$\begin{array}{l}\text { Paying zakat through institutions is positive because it can provide } \\
\text { more impactful benefit to society. }\end{array}$ & Kasri, 2013 \\
$\begin{array}{l}\text { Zakat payment through institutions is beneficial for me in fulfilling my } \\
\text { obligations as a Muslim and muzaki. }\end{array}$ & Jamal et al., 2019 \\
$\begin{array}{l}\text { Zakat payment through institutions suits my belief. } \\
\text { Paying zakat through institutions would give me peace of mind. }\end{array}$ & Alam et al., 2012 \\
\hline
\end{tabular}

\section{Subjective Norms}

Most people who are important to me think that I should pay zakat through institutions.

Mittelman and Rojas-Mendez, 2018

My family is expecting me to pay zakat through institutions.

Alam et al., 2012

It is expected that I pay zakat through institutions.

Kasri, 2013

When it comes to the matter of zakat payment, I would like to be the same as my friends.

Kasri, 2013

People I listen to could influence me to pay zakat through institutions.

Perceived Behavioral Control

I am confident that I will pay zakat through an institution in my next zakat donation.

Alam et al., 2012

If I wanted to, I could pay zakat through institutions.

Alam et al., 2012

The decision to pay zakat through institutions is entirely in my control.

Mittelman and Rojas-Mendez, 2018

I have the resources, ability and knowledge to pay zakat through an institution.

Alam et al., 2012

Alam et al., 2012

Perceived Ease of Use

Zakat institutions provide a more effective and efficient alternative to pay my zakat.

Jamaludin et al., 2017

Paying zakat through institutions provides convenience in terms of time.

Jamaludin et al., 2017

\begin{tabular}{ll}
\hline Knowledge & \\
\hline I know how zakat institution. distribute the zakat. & Zaenal and Saoqi, 2020 \\
I am aware that Indonesia has regulations on zakat. & Zaenal and Saoqi, 2020 \\
$\begin{array}{l}\text { I am aware that zakat can only be distributed to eight asnaf. } \\
\text { I know that if a salary is beyond the nishab and haul it is mandatory to } \\
\text { pay zakat.check changes OK }\end{array}$ & Zaenal and Saoqi, 2020 \\
\hline Trust & Zaenal and Saoqi, 2020 \\
\hline $\begin{array}{l}\text { I believe that zakat institutions can be trusted. } \\
\begin{array}{l}\text { I believe that zakat institutions collect zakat funds following } \\
\text { I believe that zakat institutions distribute zakat fund. following } \\
\text { regulations. }\end{array}\end{array}$ & Kasri and Ramli, 2019 \\
\hline
\end{tabular}


Table 3.

Latent Variable Indicators (Continued)

\begin{tabular}{lc}
\hline \multicolumn{1}{c}{ Indicator } & Adopted From \\
\hline $\begin{array}{l}\text { I believe that zakat institutions have similar values to me. } \\
\text { I believe that zakat institutions manage zakat funds with transparency } \\
\text { and professionalism. }\end{array}$ & $\begin{array}{c}\text { Jamal et al., 2019 } \\
\text { Kasri and Ramli, 2019 }\end{array}$ \\
\hline Intention & $\begin{array}{c}\text { Alam et al., 2012 } \\
\text { I want to pay zakat through institutions. }\end{array}$ \\
$\begin{array}{l}\text { I intend to pay zakat through institutions. } \\
\text { I am likely pay zakat through an institution. }\end{array}$ & $\begin{array}{c}\text { Mittelman and Rojas-Mendez, } \\
\text { Alam et al., 2012 }\end{array}$ \\
I expect to pay zakat through an institution in the future. & $\begin{array}{c}\text { Mittelman and Rojas-Mendez, } \\
2018\end{array}$ \\
\hline
\end{tabular}

Source: Various sources, compiled by the authors.

\subsection{Method}

Following Hair et al. (2011), this research used partial least squares - structural equation modelling (PLS-SEM) with SmartPLS software to evaluate the measurement and structural model. SEM is a statistical technique to simultaneously test and estimate the causal relationships between many independent and dependent constructs (Nils \& Ahlemann, 2016). It is considered to be a secondgeneration approach that can simultaneously examine the relationships between multiple variables (Hair et al., 2013). Furthermore, this method was used because PLS is a suitable instrument for such exploratory study (Henseler, Ringle \& Sinkovics, 2009).

After the model was specified and identified further by the literature review, the data collection was performed. For the assessment of the reflective constructs of the data, the reliability and validity of the indicators were computed, which involved outer loadings, composite reliability and Cronbach's alpha for internal consistency, average variance extracted (AVE) for convergent validity, and discriminant validity through the Fornell-Larcker criterion (Abbasi, Ting, Hlavacs, Costa \& Veloso, 2019). For the structural model, assessment was made to determine the model's predictive power and to observe the proposed constructs' hypothesised relationships. The R-square values reflected the model's predictive power, while the path coefficients indicated the strength of the hypothesised relationships.

\section{RESULTS AND ANALYSIS}

\subsection{Results}

The respondents' demographic characteristics and zakat payment preferences are shown in Table 3. The majority who pay zakat maal are female (57.9\%). In terms of age, the largest group (42.1\%) were young people between 21 and 30 years old, followed by those between 31 and 40 years old (29.9\%). 13.5\% of the respondents were between 41 and 50 years old, 10.2\% between 51 and 60 years old, and $4.3 \%$ were older than 60 . Interestingly, most of the respondents had an income or salary above IDR10 million (31.6\%) or less than IDR5.4 million $(28.9 \%)$. The proportion 
of the remaining respondents with incomes of between IDR 5.4 million and IDR7.5 million and between IDR7.5 million and IDR10 million was similar, at around $19.7 \%$.

When the respondents were asked the question about their usual zakat payment mode, the majority answered that they usually paid zakat maal through zakat institutions (36.6\%). This was closely followed by the preference to pay zakat through non-zakat institutions or directly (32.6\%). Interestingly, a relatively high number $(30.9 \%)$ of the respondents answered that they usually paid zakat through both options. Over half of those surveyed responded that they paid zakat maal one to three times per year (61.5\%). However, around 32.2\% paid seven to 12 times per year, indicating that they paid zakat from their salaries every month. Only $6.3 \%$ of the respondents paid zakat maal 4-6 times per year.

Table 4.

Demographic Statistics of the Respondents

\begin{tabular}{|c|c|c|}
\hline Variable & Frequency & $(\%)$ \\
\hline \multicolumn{3}{|l|}{ Gender } \\
\hline Male & 128 & 42.1 \\
\hline Female & 176 & 57.9 \\
\hline \multicolumn{3}{|l|}{ Age } \\
\hline $21-30$ & 128 & 42.1 \\
\hline $31-40$ & 91 & 29.9 \\
\hline $41-50$ & 41 & 13.5 \\
\hline $51-60$ & 31 & 10.2 \\
\hline$>60$ & 13 & 4.3 \\
\hline \multicolumn{3}{|l|}{ Income per month } \\
\hline$<$ IDR5,400,000 & 88 & 28.9 \\
\hline IDR5,400,001 - IDR7,500,000 & 60 & 19.7 \\
\hline IDR7,500,001 - IDR10,000,000 & 60 & 19.7 \\
\hline > IDR10,000,001 & 96 & 31.6 \\
\hline \multicolumn{3}{|l|}{ Mode of paying zakat maal } \\
\hline Zakat institution & 111 & 36.5 \\
\hline Non-zakat institution & 99 & 32.6 \\
\hline Both & 94 & 30.9 \\
\hline \multicolumn{3}{|c|}{ Frequency of paying zakat maal per year } \\
\hline 1-3 times & 187 & 61.5 \\
\hline 4-6 times & 19 & 6.3 \\
\hline 7-12 times & 98 & 32.2 \\
\hline
\end{tabular}

Source: Authors' findings.

The research found no problems in the initial test for validity and reliability. Nevertheless, when the initial Fornell-Larcker criterion was checked, it emerged that it had not been qualified as the perceived ease of use (PEU) variable had a lower number than its squared correlation with any other construct (Abbasi et al., 2019). Hence, two constructs were removed from the PEU to fulfil the criterion, withthe revision presented in Table 4 . After the issue was solved, the validity and reliability test was re-run. 
Table 5.

Fornell-Lacker Criterion

\begin{tabular}{lccccccc}
\hline & Attitude & Intention & Knowledge & PBC & PEU & SN & Trust \\
\hline Attitude & 0.912 & & & & & & \\
Intention & 0.860 & 0.942 & & & & & \\
Knowledge & 0.452 & 0.372 & 0.693 & & & & \\
PBC & 0.702 & 0.718 & 0.396 & 0.780 & & & \\
PEU & 0.725 & 0.723 & 0.396 & 0.779 & 0.932 & & \\
SN & 0.765 & 0.733 & 0.478 & 0.533 & 0.548 & 0.773 & \\
Trust & 0.570 & 0.571 & 0.450 & 0.588 & 0.571 & 0.389 & 0.924 \\
\hline \multicolumn{2}{l}{ Source: Authors' findings. }
\end{tabular}

The outer loading should exceed a minimum of 0.4 to be qualified as a research item in order to maintain convergent validity (Abbasi et al., 2019). Based on the findings, the outer loadings were qualified because their lowest value was i0.508, as shown in Table 5. Furthermore, the validity and reliability tests were demonstrated in Table 5. All of the scores of Cronbach's alpha (CA), composite reliability (CR), and average variance extracted (AVE) were higher than the suggested values of $0.70,0.70$, and 0.50 , respectively, apart from the knowledge construct, which was only 0.481 . Nevertheless, since the composite reliability was higher than 0.60 , the AVE value of below 0.5 was still acceptable because the construct's convergent validity was adequate (Fornell \& Larcker, 1981).

In addition, the squared multiple correlations (R-squared) are presented in Table 5. The hypothesis model that influenced intention and attitude had $R$ squares of 0.784 and 0.373 . These results indicate that the observed variables could explain $78.4 \%$ and $37.3 \%$ of the variation in intention and attitude.

Table 6.

Test for Outer Loadings, Reliability, Validity, and R-Squared

\begin{tabular}{lcccccc}
\hline Construct & Item & Loading & CA & CR & AVE & R2 \\
\hline \multirow{4}{*}{ Attitude } & Att1 & 0.861 & & & & \\
& Att2 & 0.908 & & & & \\
& Att3 & 0.939 & 0.949 & 0.961 & 0.832 & 0.373 \\
& Att4 & 0.921 & & & & \\
Intention & Att5 & 0.929 & & & & \\
& Int1 & 0.964 & & & & \\
& Int2 & 0.976 & 0.957 & 0.969 & 0.888 & 0.784 \\
Knowledge & Int3 & 0.967 & & & & \\
& Int4 & 0.857 & & & & \\
& Know1 & 0.573 & & & & \\
& Know2 & 0.508 & 0.707 & 0.779 & & \\
\hline
\end{tabular}


Table 6.

Test for Outer Loadings, Reliability, Validity, and R-Squared (Continued)

\begin{tabular}{|c|c|c|c|c|c|c|}
\hline Construct & Item & Loading & $\mathrm{CA}$ & $\mathrm{CR}$ & AVE & R2 \\
\hline \multirow{5}{*}{ Subjective Norms } & SN1 & 0.904 & \multirow{5}{*}{0.831} & \multirow{5}{*}{0.878} & \multirow{5}{*}{0.598} & \\
\hline & SN2 & 0.887 & & & & \\
\hline & SN3 & 0.842 & & & & \\
\hline & SN4 & 0.589 & & & & \\
\hline & SN5 & 0.576 & & & & \\
\hline \multirow{4}{*}{$\begin{array}{l}\text { Perceived } \\
\text { Behavioral } \\
\text { Control }\end{array}$} & PBC1 & 0.826 & \multirow{4}{*}{0.806} & \multirow{4}{*}{0.861} & \multirow{4}{*}{0.608} & \\
\hline & $\mathrm{PBC} 2$ & 0.788 & & & & \\
\hline & РВC3 & 0.747 & & & & \\
\hline & PBC4 & 0.756 & & & & \\
\hline \multirow{2}{*}{$\begin{array}{l}\text { Perceived Ease } \\
\text { of Use }\end{array}$} & PEU1 & 0.941 & \multirow{2}{*}{0.849} & \multirow{2}{*}{0.930} & \multirow{2}{*}{0.869} & \\
\hline & PEU2 & 0.923 & & & & \\
\hline \multirow{5}{*}{ Trust } & Tr1 & 0.937 & \multirow{5}{*}{0.957} & \multirow{5}{*}{0.967} & \multirow{5}{*}{0.854} & \\
\hline & $\operatorname{Tr} 2$ & 0.887 & & & & \\
\hline & $\operatorname{Tr} 3$ & 0.953 & & & & \\
\hline & $\operatorname{Tr} 4$ & 0.910 & & & & \\
\hline & $\operatorname{Tr} 5$ & 0.933 & & & & \\
\hline
\end{tabular}

Source: Authors' Own.

An assessment of the structural model was made to determine its predictive power and analyse the latent construct's hypothesised relationship. Moreover, the structural model assessment was analysed further by the bootstrapping procedure with 5,000 bootstrap samples. The strength of the hypothesised relationship can be determined by utilising the path coefficients. At the same time, the predictive power of the model can be denoted by using R-squared.

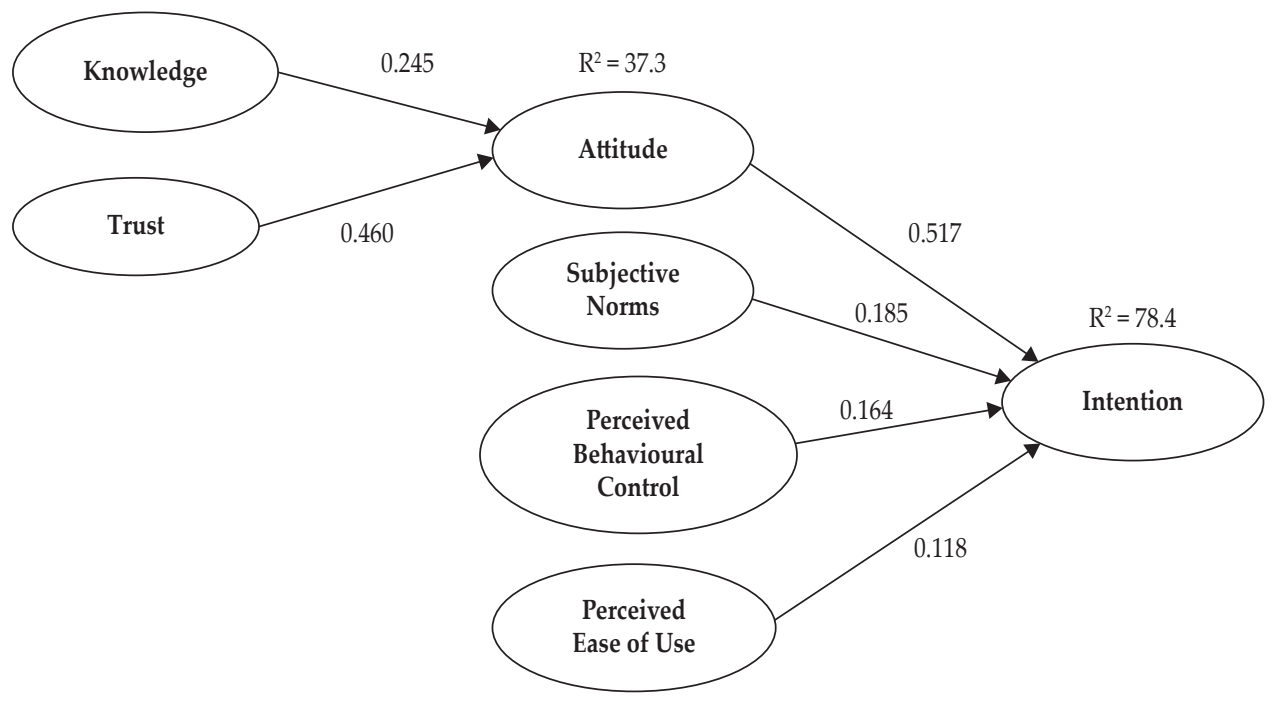

Source: Authors' own elaboration.

Figure 3.

Structural Model Assessment 
The structural model analysis findings cover the significant standardised path coefficients, and the $t$-values for each relationship are shownin Table 6 and Figure 3. As can be seen, all the hypotheses were supported. The original TPB variables by Ajzen (1991), as presented in H1, H2, and H3, were positively significant. PEU (H4) as an extended variable was considered to have a positive and significant relation to intention, even though its $\mathrm{p}$-value was the highest. In addition, the other extended variables, knowledge (H5) and trust (H6), were discovered to have a positive and significant impact on the attitude variable $(\mathrm{p}<0.05)$.

Table 7.

SEM Empirical Results

\begin{tabular}{lccccc}
\hline Hypothesis & Relationship & $\begin{array}{c}\text { Original } \\
\text { Sample }\end{array}$ & $\begin{array}{c}\text { Standard } \\
\text { Deviation }\end{array}$ & t-value & p-value \\
\hline H1 & Attitude -> Intention & 0.517 & 0.066 & 7.859 & 0.000 \\
H2 & SN -> Intention & 0.185 & 0.056 & 3.333 & 0.000 \\
H3 & PBC -> Intention & 0.164 & 0.055 & 2.986 & 0.001 \\
H4 & PEU -> Intention & 0.118 & 0.065 & 1.816 & 0.035 \\
H5 & Knowledge -> Attitude & 0.245 & 0.059 & 4.166 & 0.000 \\
H6 & Trust -> Attitude & 0.460 & 0.057 & 8.101 & 0.000 \\
\hline
\end{tabular}

Source: Authors' Own.

\subsection{Analysis}

The research has attempted to investigate muzaki intention and attitude in paying zakat maal through institutions. As one of the pillars of Islam, it is an obligation for muzak to pay zakat. The r-squared of intention was 0.784 , which shows that all the variables were considered to be crucial components of the muzaki determination to fulfil their obligation to zakat. Moreover, the research obtained validated and reliable results from the questionnaire, which confirmed the usefulness of the extended TPB model in examining the intention to donate or pay charitable funds through institutions (Kashif et al., 2015; Kasri \& Ramli, 2019; Knowles et al., 2012; Saad et al., 2020; Widiyanto et al., 2019). It is also worth noting that all of the hypotheses were accepted based on the findings.

Attitude, subjective norms, and perceived behavioral control, following from Ajzen (1991), had a significant impact on intention. The study indicates that attitude had a significant positive effect on intention, which was in line with similar previous research, such as that of Ali et al. (2017), Bidin et al. (2009) and Farouk et al. (2018). It suggested that if paying zakat through institutions has a more significant impact for both muzaki and mustahik, such a payment method will be preferred by muzaki. This finding could be explained by the fact that most muzaki assess the distribution and empowerment of mustahik, and if this is regarded as successful, it could shape the preference of muzaki's zakat payment through amil institutions.

Furthermore, the research strengthens the argument that subjective norms significantly and positively influence intention. In other words, those close to muzaki could direct them to make decisions on channelling zakat funds. This result also indicates the prominence of social agreement around muzaki, and that 
public figures' encouragement impacts intention. Therefore, it is recommended to conduct socialisation regarding the payment zakat to those close to muzaki, such as friends, working partners, or families (Sapingi et al., 2011) and public figures.

Moreover, PBC had a significant and positive influence on intention. This indicates that the ability to pay zakat through institutions could encourage stronger intentions (Knowles et al., 2012; Mittelman \& Rojas-Méndez, 2018) for muzaki to pay through them. In other words, a higher ability and willingness of muzaki will lead to a stronger intention by them to pay zakat through amil institutions.

Finally, the additional variable PEU had a positive and significant impact on intention. When muzaki have easier access by using zakat institutions, whether online or on-site, this could create a demand for them to pay zakat through institutions (Jamaludin et al., 2017; Poon, 2008). This notion highlights the vital role of innovation that was expected to be adopted by the institutions to ensure that muzaki are provided with ease in paying zakat.

This research proposed two additional variables for enhancement: knowledge and trust to attitude. The study has articulated existing studies such as those of Bagheri, Chitsazan \& Ebrahimi (2019) and Jamal et al. (2019), in which TPB was extended with other variables. It was found that knowledge had a positive and significant impact on attitude. This research argues that sufficient knowledge related to zakat, such as its rightful recipients, the minimum rates of zakat, how institutions distribute zakat and supporting regulations, could increase the attitude of muzaki. The knowledge of Islamic values and the impactful distribution of zakat could inspire them to give to charity. It is also essential for muzaki to be aware of the favourable zakat payment regulations, such as tax deductions. Therefore, the method of paying zakat through institutions can be enhanced.

As hypothesised, the influence of trust on attitude was also accepted. The findings validate previous research (Kasri \& Ramli, 2019; Widiyanto et al., 2019), emphasising that the credibility of zakat institutions in managing zakat funds could influence the choice of muzaki and the preference of the Muslim community. Therefore, the results imply the importance of the zakat institution'accountability and transparency in order to raise society's trust.

\section{CONCLUSION AND RECOMMENDATIONS}

\subsection{Conclusion}

As discussed above, it is an anomaly that Indonesia, with the largest Muslim population and as the world's most generous nation, has low zakat realisation. On the other hand, the typology of zakat regulation in Indonesia that does not make it mandatory, thus necessitating comprehensive understanding of the human interest in zakat compliance behaviour. Therefore, by utilising the theory of planned behavior to identify the factor of zakat compliance behavior, the research has filled gaps in the literature, thus indirectly contributing to an increase in zakat collection.

TPB can be used as a practical framework to predict the intention of muzaki to pay zakat through institutions. This research has demonstrated that it can be applied to Islamic social finance-related studies. The online questionnaire was applied in the lockdown period to gather data from respondents across Indonesia. Selected 
data were processed, and the results show that all the proposed hypotheses were accepted. Attitude, subjective norms, PBC, and PEU have linear and significant impacts on the intention of muzaki to pay zakat maal. The influence of attitude on intention implies that paying zakat through institutions is preferable for muzaki if their donations can have a more significant impact and if the process matches the value that muzaki have. Those close to muzaki are also essential in creating their zakat payment preferences, as subjective norms is a significant variable.

Moreover, the positive impact of $\mathrm{PBC}$ on intention shows that the greater the ability of influence to pay zakat through institution can shape intention. The final variable, PEU, also influences behaviour and hence innovation, which can assist muzaki in paying zakat, so is a crucial observed element. Furthermore, knowledge and trust have positive and significant relations with attitude. This implies that information and transparency should be improved to ensure that muzaki have a favourable attitude towards zakat payment.

These findings are relevant, especially during the current pandemic period, to fulfil the potential of zakat collection. By understanding muzaki preferences, amil institutions can formulate strategic and efficient distribution of zakat that has been scientifically proven, so they can shape the preference of muzaki to pay zakat through amil institutions.

\subsection{Recommendations}

These study findings suggest several courses of action for practitioners and regulators in the zakat field. Zakat knowledge has been proven to be essential in directing muzaki's perspectives towards zakat institutions. Therefore, the managers of these institutions should provide the necessary information, such as how zakat funds are distributed to only eight rightful recipients. Moreover, the institutions need to communicate the distribution reports to the muzaki, especially if the funds can reach impoverished people who they might never meet or know. It is also important to emphasise the concepts of nishab and haul, which are fundamental in zakat payment awareness. This kind of information can be informed periodically with helpful guidance from amil when the muzaki pay zakat. To create easier channels for zakat payment, managers could accommodate contemporary payment methods such as using e-wallets or mobile transfer. Managers could create online posters or short videos, while banners could be promoted in strategic areas to catch muzaki's attention. There should be further market research to comprehend demand, and preference campaigns to attract society.

On the BAZNAS side, as the coordinator of Indonesia zakat institutions and the regulator, they should develop strategies to promote the paying of zakat through institutions. In raising knowledge, BAZNAS can socialise with a larger group of muzaki to significantly create benevolent views of the institutions' role. The socialisation can be accomplished in work offices, amongst groups of students, or families, and reflected in subjective norms. The knowledge can initially focus on how the institutions' distribution and regulations support zakat payment through them. The highlight of zakat distribution is to transfer money and improve the lot of mustahik, together with building their lives with supporting programmes. BAZNAS should conduct campaigns on how the zakat funds from muzaki can have 
visible impacts. For instance, when funds are distributed for university students' education, zakat institutions could exhibit the students' testimonies showing how their living standards have improved because they were able to secure established jobs. In this way, the trust of muzaki is built and brings a better perspective on paying zakat via institutions.

However, there are several limitations to this research. First, it only focused on zakat maal payment. Further research could explore other types of zakat in further detail, such as commercial, income and agriculture, which are also parts of zakat worship. Second, there might be potential sample bias as most of the respondents were from Java and Sumatra islands, where the number of zakat institutions is higher than in other regions in Indonesia. Finally, it would be interesting to investigate the situation in other countries with different zakat typologies. This could enrich understanding of the factors that influence muzaki to pay zakat through zakat institutions in various environments.

\section{REFERENCES}

Abbasi, A. Z., Ting, D. H., Hlavacs, H., Costa, L. V., \& Veloso, A. I. (2019). An empirical validation of consumer video game engagement: A playfulconsumption experience approach. Entertainment Computing, 29(March 2019), 43-55. https://doi.org/10.1016/j.entcom.2018.12.002.

Ajzen, I., \& Fishbein, M. (1980). Understanding attitudes and predicting social behaviour. Englewood Cliffs: Prentice-Hall.

Ajzen, I. (1991). The theory of planned behavior organizational behavior and human decision processes. Organizational Behavior and Human Decision Processes, 50(2), 179-211.

Ajzen, I. (2011). The theory of planned behaviour: Reactions and reflections. Psychology and Health, 26(9), 1113-1127.

Ajzen, I. (2015). Consumer attitudes and behavior: The theory of planned behavior applied to food consumption decisions. Rivista di Economia Agraria, 70(2), 121138. https://doi.org/10.13128/REA-18003.

Alam, S. S., Janor, H., Zanariah, Wel, C. A. C., \& Ahsan, M. N. (2012). Is religiosity an important factor in influencing the intention to undertake Islamic home financing in Klang Valley? World Applied Sciences Journal, 19(7), 1030-1041. https://doi.org/10.5829/idosi.wasj.2012.19.07.392.

Ali, M. A. M., Tazilah, M. D. A. B. K., Shamsudin, A. I. Bin, Shukri, F. R. B. F., Adelin, N. M. F. A. B. N., \& Zaman, W. M. S. B. W. Z. (2017). Factors that influence the zakat collection funds: A case in Kuantan. South East Asia Journal of Contemporary Business, Economics and Law, 13(1), 30-37.

Ali, I., \& Hatta, Z. A. (2014). Zakat as a poverty reduction mechanism among the Muslims community: A case study of Bangladesh, Malaysia, and Indonesia. Asian Social Work and Policy Review, 8(1), 59-70. http://doi.org/10.1111/ aswp.12025.

Amin, H. (2008). Choice criteria for Islamic home financing: Empirical investigation among Malaysian bank customers. International Journal of Housing Markets and Analysis, 1(3), 256-274. 
Asian Development Bank. (2020). Asian development outlook 2020: What drives innovation in Asia? Adb, 1-391.

Bagheri, A., Chitsazan, H., \& Ebrahimi, A. (2019). Crowdfunding motivations: A focus on donors' perspectives. Technological Forecasting and Social Change, 146(April), 218-232. https://doi.org/10.1016/j.techfore.2019.05.002.

BAZNAS. (2019). Outlook zakat Indonesia 2020. Pusat Kajian Strategis - Badan Amil Zakat Nasional (PUSKAS BAZNAS).

BAZNAS. (2020). Laporan BAZNAS Dalam Penanganan COVID-19.

Beik, I. S. (2015). Towards international standardization of zakat system. Figh Zakat International Conference 2015, November, 3-17. https://doi.org/10.13140/ RG.2.1.4490.1207.

Beik, I. S., \& Arsyianti, L. D. (2016). Measuring zakat impact on poverty and welfare using Cibest model. Journal of Islamic Monetary Economics and Finance, 1(2), 141-160. https://doi.org/10.21098/jimf.v1i2.524.

Beik, I. S., \& Pratama, C. (2016). Zakat impact on poverty and welfare of mustahik: A CIBEST model approach. AFEBI Islamic Finance and Economic Review, 1(1), 1-12. http://journal.afebi.org/index.php/aifer/article/view/16.

Bidin, Z., Idris, K. M., \& Shamsudin, F. M. (2009). Predicting compliance intention on zakah on employment income in malaysia: An application of reasoned action theory. Jurnal Pengurusan, 28(2009), 85-102. https://doi.org/10.17576/ pengurusan-2009-28-05.

Charities Aid Foundation (CAF). (2018). CAF world giving index 2018: A global view of giving trends (Issue October).

Check, J., \& Schutt, R. (2011). Research methods in education. California: Sage Publications.

Chomeya, R. (2010). Quality of psychology test between likert scale 5 and 6 points. Journal of Social Sciences, 6(3), 399-403.

Davis, F. D. (1989). Perceived usefulness, perceived ease of use, and user acceptance of information technology. MIS Quarterly: Management Information Systems, 13(3), 319-339. https://doi.org/10.2307/249008.

Farouk, A. U., Md Idris, K., \& Saad, R. A. J. Bin. (2018). Moderating role of religiosity on Zakat compliance behavior in Nigeria. International Journal of Islamic and Middle Eastern Finance and Management, 11(3), 357-373. https://doi.org/10.1108/ IMEFM-05-2017-0122.

Firdaus, M., Beik, I. S., Irawan, T., \& Juanda, B. (2012). Economic estimation and determinations of Zakat potential in Indonesia. IRTI Working Paper Series, WP 1433-07(August), 1-74.

Firmansyah, I., \& Devi, A. (2017). The implementation strategies of good corporate governance for zakat institutions in Indonesia. International Journal of Zakat, 2(2), 85-97. https://doi.org/10.37706/ijaz.v2i2.27.

Fishbein, M., \& Ajzen, A. (2011). Predicting and changing behavior: The reasoned action approach. New York: Taylor \& Francis.

Fornell, C., \& Larcker, D. F. (1981). Evaluating structural equation models with unobservable variables and measurement error. Journal of Marketing Research, 18(1), 39-50. https://doi.org/10.2307/3151312.

Hair, J. F., Hult, G. T. M., Ringle, C. M., \& Sarstedt, M. (2013). A primer on partial least squares structural equation modeling (PLS-SEM). Thousand Oaks: Sage. 
Hair, J. F., Black, W. C., Babin, B. J., \& Anderson, R. E. (2010). Multivariate data analysis: Global edition (7th Edition). London: Pearson Education.

Hair, J. F., Ringle, C. M., \& Sarstedt, M. (2011). PLS-SEM: Indeed a silver bullet. Journal of Marketing Theory and Practice, 19(2), 139-152. https://doi.org/10.2753/ MTP1069-6679190202.

Henseler, J., Ringle, C. M., \& Sinkovics, R. R. (2009). The use of partial least squares path modeling in international marketing. Advances in International Marketing, 20, 277-319. https://doi.org/10.1108/S1474-7979(2009)0000020014.

Huda, N. (2014). Solution of zakat problem in Indonesia with modification action research. Human Falah, 1(1), 40-62.

Husin, M. M., \& Rahman, A. A. (2016). Do Muslims intend to participate in Islamic insurance?: Analysis from theory of planned behaviour. Journal of Islamic Accounting and Business Research, 7(1), 42-58. https://doi.org/10.1108/ JIABR-03-2014-0012.

Hussey, J., \& Hussey, R. (1997). Business research: A practical guide for graduates and postgraduates. London: Palgrave Publishing.

Ibrahim, M. A., Fisol, W. N. M., \& Haji-Othman, Y. (2017). Customer intention on Islamic home financing products: An application of theory of planned behavior (TPB). Mediterranean Journal of Social Sciences, 8(2), 77-86. https://doi. org/10.5901/mjss.2017.v8n2p77.

IMF (2020). Global Financial Stability Report: Markets in the Time of COVID-19. Imf, April, 1-28.

Jaffar, M. A., \& Musa, R. (2016). Determinants of attitude and intention towards Islamic financing adoption among non-users. Procedia Economics and Finance, 37(16), 227-233. https://doi.org/10.1016/s2212-5671(16)30118-6.

Jamal, A., Yaccob, A., Bartikowski, B., \& Slater, S. (2019). Motivations to donate: Exploring the role of religiousness in charitable donations. Journal of Business Research, 103(February), 319-327.

Jamaludin, N., Wahab, N. A. B. D., \& Hamed, A. B. U. B. (2017). Muslims perception on online zakat usage in Kuala Lumpur. Journal of Muamalat and Islamic Finance Research, 14(1), 55-71.

Kashif, M., Sarifuddin, S., \& Hassan, A. (2015). Charity donation: Intentions and behavior. Marketing Intelligence and Planning, 33(1), 90-102. https:/doi. org/10.1108/MIP-07-2013-0110.

Kasri, R. A. (2013). Giving behaviors in Indonesia: Motives and marketing implications for Islamic charities. Journal of Islamic Marketing, 4(3), 306-324. https://doi.org/10.1108/JIMA-05-2011-0044.

Kasri, R. A., \& Ramli, U. H. (2019). Why do Indonesian Muslims donate through mosques?: A theory of planned behaviour approach. International Journal of Islamic and Middle Eastern Finance and Management, 12(5), 663-679. https://doi. org/10.1108/IMEFM-11-2018-0399.

Knowles, S. R., Hyde, M. K., \& White, K. M. (2012). Predictors of young people's charitable intentions to donate money: An extended theory of planned behavior perspective. Journal of Applied Social Psychology, 42(9), 2096-2110. https://doi. org/10.1111/j.1559-1816.2012.00932.x.

Mittelman, R., \& Rojas-Méndez, J. (2018). Why Canadians give to charity: An extended theory of planned behaviour model. International Review on Public 
and Nonprofit Marketing, 15(2), 189-204. https://doi.org/10.1007/s12208-0180197-3.

Mukhlis, A., \& Beik, I. S. (2013). Analisis faktor-faktor yang memengaruhi tingkat kepatuhan membayar zakat: Studi kasus Kabupaten Bogor. Al-Muzara'ah, 1(1), 83-106. https://doi.org/10.29244/jam.1.1.83-106.

Nils, U., \& Ahlemann, F. (2016). Lekkende borsten, gammele kleppen en kleverige matjes. Nederlands Tijdschrift Voor Geneeskunde, 160(12-13), 5-40.

Pitchay, A., Thaker, A. B. M. T, Azhar, Z., Mydin, A., \& Thaker, H. (2019). Factors persuade individuals' behavioral intention to opt for Islamic bank services: Malaysian depositors' perspective. Journal of Islamic Marketing, 11(1), 234-250.

Poon, W. C. (2008). Users' adoption of e-banking services: The Malaysian perspective. Journal of Business and Industrial Marketing, 23(1), 59-69. https:// doi.org/10.1108/08858620810841498.

Qardawi, Y. (2000). Figh al zakah: A comparative study of zakah, regulations and philosophy in the light of qur'an and sunnah (Vol.1). Sharjah: Dar Ul Thaqafah.

Sapingi, R., Ahmad, N., \& Mohamad, M. (2011). A study on zakah of employment income: Factors that influence academics intention to pay zakah. 2nd International Conference on Business and Economic Research (2nd ICBER 2011) Proceeding, 2492-2507.

Saad, R. A. J., Farouk, A. U., \& Kadir, D. A. (2020). Business zakat compliance behavioral intention in a developing country. Journal of Islamic Accounting and Business Research, 11(2), 511-530. https://doi.org/10.1108/JIABR-03-2018-0036.

Saad, R. A. J., \& Haniffa, R. (2014). Determinants of zakah (Islamic tax) compliance behavior. Journal of Islamic Accounting and Business Research, 5(2), 182-193. https://doi.org/10.1108/JIABR-10-2012-0068.

Smith, J. R., \& McSweeney, A. (2007). Charitable giving: The effectiveness of a revised theory of planned behaviour model in predicting donating intentions and behaviour. Journal of Community \& Applied Social Psychology, 17(5), 363386. https://doi.org/10.1002/casp.

Suryahadi, A., Al Izzati, R., \& Suryadarma, D. (2020). The Impact of COVID-19 outbreak on poverty: An estimation for Indonesia (Draft). SMERU Working Paper, April, 1-20.

Taib, F. M., Ramayah, T., \& Abdul Razak, D. (2008). Factors influencing intention to use diminishing partnership home financing. International Journal of Islamic and Middle Eastern Finance and Management, 1(3), 235-248. https://doi. org/10.1108/17538390810901168.

Wahab, N. A., \& Rahman, A. R. A. (2011). A framework to analyse the efficiency and governance of zakat institutions. Journal of Islamic Accounting and Business Research, 2(1), 43-62. https://doi.org/10.1108/17590811111129508.

Widiyanto, W., Zaenudin, Z., Santoso, B., \& Sumiati, S. (2019). A study of Indonesian community's behaviour in paying zakat. Journal of Islamic Marketing, 11(4), 961-976. https://doi.org/10.1108/JIMA-10-2018-0208.

World Bank. (2020). East Asia and Pacific Economic Update, Part III. Country Summaries and Key Indicators.

Yusuf, M. B. O., \& Derus, A. M. (2013). Measurement model of corporate zakat collection in Malaysia: A test of diffusion of innovation theory. Humanomics, 29(1), 61-74. https://doi.org/10.1108/08288661311299321. 
This page is intentionally left blank 